\title{
Economic Integration in the ECOWAS: Implications for Financial Intermediation in Nigeria
}

\author{
David E. Omoregie ${ }^{1^{*}} \quad$ Ifeoma B. Ezike ${ }^{2}$ \\ 1.Assistant Director (Economics), Monetary Policy Department, Central Bank of Nigeria \\ 2.Principal Economist, Monetary Policy Department, Central Bank of Nigeria
}

\begin{abstract}
The study employed the autoregressive distributed lag (ARDL) approach to co-integration to estimate a set of four models with a view to examining the impact of ECOWAS integration on financial intermediation in Nigeria, which was differentiated by type of financial development indicators (FD) used as dependent variable in the different models. The dependent variables were the proxies for financial intermediation in Nigeria, namely; ratio of credit to private sector provided by commercial banks to national GDP (CPS_GDP); ratio of broad money supply (M2) to GDP (M2 GDP); and ratio of commercial bank's assets to the combination of commercial banks' and central bank's assets (COMB_ASSETS). A composite measure of the three financial intermediation indicator was also used in the fourth model. The study data ranged from 1960 to 2018, and comprised Nigerian and ECOWAS macroeconomic variables obtained from different sources. ADF test was conducted to test for unit root and the result showed that the variables have a unit root. Across the four models, the results of the study showed that ECOWAS regional economic integration does not significantly influence the degree of financial intermediation in Nigeria, and may not be promoting development of the Nigerian financial sector. On the contrary, domestic macroeconomic developments are, however, more supportive of financial intermediation in Nigeria, and suggest the need to improve monetary conditions and credit access and availability. It has become imperative, therefore, to carry out a cost-benefit and impact analyses of the region's integration to help reposition the country for its benefits.
\end{abstract}

Keywords: economic integration, financial intermediation, autoregressive distributed lag (ARDL), co-integration, ECOWAS, Nigeria

JEL Classification: E44, F36, G2, G32, G21.

DOI: $10.7176 / \mathrm{JESD} / 11-4-06$

Publication date: February $29^{\text {th }} 2020$

\section{Introduction}

Economic integration among West African States, popularly known as ECOWAS, comprising 15 countries in that region, aims to foster and accelerate the economic and social development of member states. The region, which is home to about 240 million people, has an average per capita income of about US\$300, with about $50 \%$ of its people living in absolute poverty. The Community's original purpose was to establish an economic cooperation, allowing adoption of common financial, economic, social, and cultural policies, ultimately leading to creating a monetary union. The overall goal was to stimulate economic activities and trade between member states, thereby helping to build economically viable region that guarantees prosperity for all. Since its establishment in 1975, the Community has struggled to offer some benefits to Member States, and these benefits range from free mobility of labour, increased trade among members and some levels of financial integration in the region. While most members of ECOWAS have signed on to WTO market access commitments, they have also placed restrictions on capital account transfers, with little or no capital flow among them.

A key envisaged goal of the economic integration is full-scale financial integration, with substantial potential benefits for member states' financial development and intermediation. Poor financial intermediation remains a major drag in the economic development of sub-Saharan Africa, and is a key characteristic of the financial sector of ECOWAS countries. The development continues to fuel the region's reliance on foreign capital, thereby accentuating member states' vulnerabilities to external shocks.

In recent times, global capital flow developments have been unfavorable for the developing economies, especially for those in sub-Saharan Africa, and ECOWAS countries have been severely hit. While capital inflow was substantial in the decade prior to the global financial crisis (GFC) of 2007, there has been widespread capital reversal in response to the recent appreciation of the dollar and dollar-denominated assets on account of the US Fed's normalization of monetary policy. The concomitant shortage of foreign capital is compelling ECOWAS financial institutions to look inward and develop their domestic financial markets to support savings mobilization and enhance financial intermediation. In general, financial intermediation in the region has been hindered by a number of rigidities, including high operating expenses; increased loan provisioning due to increasing nonperforming loans (NPLs) as financial institutions pursue larger market share; and instability in the policy environment.

With full scale integration, numerous benefits are expected to materialize, including access to a single regional 
market with greater liquidity, depth, and efficiency; and improved capital allocation in the region, thereby eliminating imbalances arising from national capital restrictions. In addition, there should be increased inflow of capital, as foreign investors prefer larger and more liquid regional market. Overall, a substantial reduction in the regional average cost of capital and debt is the anticipated net impact of economic integration. For most countries in the region, however, this benefit has been elusive as the region's cost of credit and debt levels continue to worsen.

In Nigeria, financial intermediation remains crucial to economic activity, and banks are the most predominant institutions in the country's financial system. The banking system is, however, characterized by moral hazards, cautious approach to lending, resulting in substantial funding gap in the real sector, and high lending rates, leading to a persistence of high spread, thereby hindering savings mobilization. In the literature, the main determinants of commercial banks' interest rate spreads have been categorised as industry (market) specific, bank-related, or macroeconomic in nature. Bank-related characteristics mainly include the ownership pattern, the size of the banks, capital adequacy, loan portfolio quality, operating expenses, size of liquid and fixed assets and overhead costs (Demirguc-Kunt and Huizinga, 1999; Ngug, 2001; Brock and Rojas-Suarez, 2000; Moore and Graigwell, 2000; Robinson, 2002; Gelos, 2006; Sologoub, 2006; Folawewo and Tennant, 2008; and Crowley, 2007).

In Nigeria, the major factors responsible for the current high lending rates include the oligopolistic structure of the banking system, and the inadequacies of infrastructural facilities that tend to drive up the cost of financial intermediation (Sanusi, 2002). High financial intermediation costs reflect poorly developed capital market and its inability to support the private sector, with severe implications for the wider economy. The constant rise in financial intermediation costs and low deposits rates continue to discourage savings mobilization (Mahmood and Bilal, 2010). The Central Bank of Nigeria, in its supervisory and regulatory oversight, has encouraged the banking system to embrace a new framework for determining banks' cost of funds, to reduce the cost of borrowing and stimulate investment and output growth in the real sector.

Financial intermediation help to mitigate the costs of information and financial transactions (Onodugo, Anowor and Kalu, 2013), impacting lending rates and credit to private sector in Nigeria. Thus, the Nigerian policy makers need evidence regarding the state of financial development as well as the determinants of financial intermediation, especially since the implementation of economic integration in the region. Therefore, this study's main objective is to identify the main indicators of financial intermediation in Nigeria and the impact economic integration in the ECOWAS region has on those indicators in the Nigerian financial system.

Following the introduction, Section 2 discusses theoretical and empirical literature. Section 3 analyzes some stylized facts, section 4 discusses methodology and model estimation, and section 5 presents model results and discussions. Section 6 discusses the conclusions of the paper along with policy implications.

\subsection{Literature Review}

\subsection{Theoretical Literature}

In sub-Saharan Africa, many countries have identified the need to pull their resources together with a view to attaining economic independence (Fayomi and Adeola, 2015). In the African Continent, this has led to seeveral economic and regional integrations, leading to the creation of regional blocks such as the Economic Community of West African States (ECOWAS), the East African Community (EAC) and Southern African Development Community (SADC).

The integration of the West African subregion led to the establishment of the ECOWAS, which was created by the endorsement of the treaty in Lagos on the 28th of May, 1975. The goal of the treaty was to develop a subregional integration expected to stimulate, foster and promote economic activities, modernization, development, and growth across Member States in the region.

The main objective of the ECOWAS in the regional economic integration is reflected in the 1975 ECOWAS Treaty thus: "It shall be the aim of the Community to promote co-operation and development in all fields of economic activity... for the purpose of ... increasing and maintaining economic stability... and ... contributing to the progress and development of the African continent." (Article 1). To achieve the goal, member states were required to harmonize their industrial and economic policies and reduce the disparities in the development of the member states. In addition, a Trade, Customs, Immigration, Monetary and Payments Commission was set up. The Revised Treaty which came into effect in 1993 reemphasized that "the aims of the Community are to promote cooperation and integration, leading to the establishment of an economic union in West Africa, in order to raise the living standards of its people and maintain and enhance economic stability". The Community also aims to ensure the harmonization of trade, finance and monetary policies across member states. It also aims to promote joint ventures in the private sector, mainly by encouraging cross-border investments, and adopt measures for the creation of an enabling environment for small and medium scale enterprises to thrive.

Economic integration involves the abolishment of inner borders' customs tariffs between two or more regions, states or economies, with a view to integrating economic activities, promoting development and spurring growth within and between the regions. The above process requires coherence of national or regional policies (customs, 
tax, financial, social policies etc, and entity registration) within integrated states, unifying economic parameters such as interest rates, tax rates, domestic savings rate etc, to single value. The expected outcome of economic integration is equal multi-dimensional economic space within integrated regions (Daimov, 2008).

Economic integration of states leads to better terms of trade and privileged position for trade negotiations. It is beneficial to growth of an economy, depending on its development stages as well as the scale of the union. For example, if there are only two states in the economic union, the larger economy would benefit less from the integration comapared to the smaller economy, which is likely to benefit more from the integration. Productivity in a unified area has been observed to have increased remarkably more in the less developed states, and vice versa (Dalimov, 2008).

Part of the benefits of economic integration is ease of accessibility or free access to the markets of the other member states. Given that economic integration entails the creation of a supranational body, it ultimately leads to pooling regional funds, thus helping to reallocate funds from the richer states to poorer and less developed states. This development can lead to equitable development among member states, thereby enhancing faster development among the less developed states, increasing their per capita incomes.

Financial intermediation is, therefore, "a process which involves surplus units depositing money with financial institutions which then lend to deficit units" (Mathews \& Thompson, 2008). Thus, financial intermediation helps to channel funds from surplus economic units (lenders) to deficit economic units (borrowers) through financial institutions. Accordingly, the role of the financial institutions is to broker the relationship between borrowers and lenders.

In contemporary literature, theoretical models recognise that financial intermediation mitigates the costs of information acquisition and financial transactions (Benston and Smith, Jr., 1975). Several other studies indicate that financial intermediation provides insurances and risk sharing (Allen and Gale, 1997, 2004), supports the financing of liquidity needs through credit lines (Holmstrom and Tirole, 1998), and helps to create specialized products (Benstom and Smith, Jr. 1975). Overall, however, there are mixed opinions about financial intermediation in general. While some researchers argue that financial intermediation promotes the efficiency of the financial system (Anad and Subrahmanyam, 2008; Gromb and Vayanos, 2010;), other strands of literature hold that it is channel of monetary policy implemenation (Benston and Smith, Jr. 1975). Further still, other researchers argue that it affects the restructuring and liquidation of distressed businesses (Araujo and Minetti, 2007).

\subsection{Empirical Literature}

The key components of financial intermediation, namely savings mobilization, risk management, project evaluation and monitoring, and facilitating transactions have been generally found to be essential for innovations, competiveness, and economic growth. A strong strand of literature is devoted to the investigation of the impact of financial development (intermediation) on economic growth.

King and Levine (1993) used a pooled cross-sectional data of eighty countries for the period 1960-1989 to investigate the relationship between economic growth and financial development. The study used four variables as proxy for financial development, namely: relative importance of specific financial institutions; proportion of credit allocated to the private sector; financial depth; and the ratio of claims on the non-financial private sector. Four variables were also used as proxy for economic growth, namely: long-run real per capital GDP; the ratio of domestic investment to GDP; residual measure of improvement in the efficiency of physical capital allocation and the rate of physical capital accumulation. The results showed that the four financial development indicators were statistically and positively related to growth and other indicators of growth.

Later on, Odedokun (1998), applied a cross-sectional data analysis of 71 less developed countries (LDCs) for the period 1960 to 1980. In the study, two models were tested, with growth as the dependent variable, along with alternative independent variables, namely: Investment-GDP ratio; labour force growth; financial depth and real export growth. The author found that although financial intermediation supports economic growth, the growthenhancing impact was predominant in the low-income countries. Using ordinary least squares (OLS) and Generalized Least Squares (GLS) methods, the study further showed a strong positive relationship between economic growth and financial intermediation.

Almost decade later, Hao (2006) repeated the same study for China to determine the relationship between economic growth and financial intermediation during the period 1985 to 1999. The author used a linear model, relating economic growth to its previous history, and other financial development indicators, namely: savings, banks and loan-budget ratio. The study finds that financial intermediation has a positive impact on growth via the twin channels of substitution of loans for state budget appropriations and households' savings mobilization.

The work of Ali (2013) investigated the relationship and dynamic linkages between financial development and economic growth in Sudan, using data for the period 1970 - 2011. It applied autoregressive distributed lag (ARDL) modeling approach to co-integration, and used three indicators of financial developments. These were the ratios of: (i) credit to private sector by commercial banks as a proportion of GDP, (ii) liquid liabilities of commercial banks to nominal GDP; and (iii) broad money supply as a percentage of GDP. In addition, the work 
included four control variables, namely trade openness, inflation, government expenditures and gross investment. It found that credit to the private sector and the liquid liabilities exert positive impact on economic growth while money supply impacts real per capita GDP negatively. By significance, only credit to the private sector affects the Sudanese economy in the long-run. In addition, government expenditure, money supply, trade openness and inflation exerted negative effects, while private credit, investment and liquidity exerted positive impact on real per capita income.

Mahawiya (2015) implemented a comparative analysis of the ECOWAS and Southern African Development Community (SADC) with regard to the impact of inflation on financial development of the economic regions. Using a dynamic panel approach, with data ranging from 1980 to 2011, the findings support that inflation is inimical to financial development with greater impact in the ECOWAS region. The study also indicates that the simultaneous increase in opening of the financial sector and trade can lead to higher level of financial development in SADC. However, trade openness on its own can still stimulate growth in the sector.

\subsection{Stylized Facts}

\subsection{Ecowas Region}

Representing $17 \%$ and $30 \%$ of Africa's surface area and population respectively, ECOWAS is the most densely populated area on the continent. It is one of the best performing regions in terms of agricultural production, accounting for 28\% of GDP at current price on the entire continent and 40\% of Sub-Saharan Africa's GDP in 2015

\subsubsection{Economic Growth in the ECOWAS Region}

In the ECOWAS, real growth has consistently been above 5\% from 2000 until 2014, driven mainly by the developments in the Nigerian economy, which is by far the region's economic powerhouse (accounting for nearly $70 \%$ of the region's GDP). After a couple of decades of substantial growth, the Nigerian economic slipped into recession in 2016, thereby slowing down the region's economy. The main reason for the significant slowdown in the region's growth dynamics is the fall in commodity prices, particularly of oil, which declined by at least $50 \%$ since the last quarter of 2014. The adverse cumulative effects of the sharp reduction in oil prices on the Nigerian economy, Africa's largest oil producer, also impacted negatively the region's growth. The development can be summed up as follows: sharp fall in export revenues, sharp depreciation of the Naira, resulting in a drop in real GDP, (see Table 2).

Although strongly significant for the region's economic growth prospects, the negative result recorded by Nigeria appears to be an isolated. Thus, in 2016, the region's economic growth, excluding Nigeria, pegged at 5.3\% against 4.7\% in 2015 (see Table 1). This positive momentum is linked to sustained growth in almost all Member States. Six of them, namely Burkina Faso (5.2\%), Cote d'Ivoire (8\%), Mali (5.3\%), Niger (5.2\%), Senegal (6.6\%) and Togo $(5.3 \%)$ sustained growth rates higher than 5\%. Real GDP grew positively in Cabo Verde (3.6\%), Guinea (3.8\%), Liberia (2\%) and Sierra Leone (4.3\% following the sharp decline of -21.1\% in 2015) (see table 2). However, although the impact of the economic recession in Nigeria appeared not felt beyond its borders, the protracted economic downturn in the country could adversely affect other countries, in particular Benin and Niger, due to the close economic ties between the Nigeria and the two countries.

\begin{tabular}{|c|r|lr|r|r|r|}
\hline \multicolumn{2}{|l|}{ Table 1: KEY INDICATORS OF THE ECOWAS REGION } \\
\hline & Nominal GDP & Real Growth rate & Real Growth rate & GDP Per Capita & Population \\
\hline & (billions of US dollar) & (\%) & (excluding Nigeria) & (US dollar) & (millions) \\
\hline $2006-2008$ & 365 & 6.5 & 4.6 & 1331.8 & 274.8 \\
\hline $2009-2011$ & 480.5 & 7.3 & 4.5 & 1606.7 & 298.4 \\
\hline $2012-2014$ & 665.7 & 5.6 & 6.4 & 298.4 & 323.7 \\
\hline 2015 & 637.4 & 3.1 & 4.7 & 323.7 & 341.6 \\
\hline 2016 & 571.4 & -2 & 5.3 & 341.6 & 350.9 \\
\hline
\end{tabular}

\footnotetext{
Calculated from IMF-WEO'S Country data, 2017
} 
Table 2. Real Growth Rate of ECOWAS Countries in Percentage BEN BFACPVCIV GMB GUI GNBLBRMLINERNGASENSLETGOGHA

\begin{tabular}{|r|r|r|r|r|r|r|r|r|r|r|r|r|r|r|r|}
\hline 2014 & 6.5 & 4 & 1.9 & 7.9 & -2 & 1.1 & 2.5 & 0.7 & 7 & 7.1 & 6.3 & 4.3 & 5 & 5.4 & 4 \\
\hline 2015 & 5 & 4 & 1.9 & 8.5 & 4.4 & 0.1 & 4.8 & 0 & 6 & 3.5 & 2.7 & 6.5 & -2 & 5.4 & 3.9 \\
\hline 2016 & 4 & 5.2 & 1.9 & 8 & 2.3 & 3.8 & 4.8 & 2 & 5.3 & 5.2 & -1 & 6.6 & 4 & 5.4 & 3.3 \\
\hline 2017 & 5.4 & 5.9 & 4 & 8 & 3.3 & 4.4 & 5 & 4 & 5.2 & 5 & 0.6 & 6.8 & 5 & 5 & 7.4 \\
\hline
\end{tabular}

Legend: BEN (Benin Republic); BFA (Burkina Faso); CPV (Cape Verde); CIV (Cote D'Ivoire) GBM (Gambia); GUI (Republic of Guinea); GNB (Guniea Bissau); LBR (Liberia); MLI (Mali); NER (Niger); NGA (Nigeria );

SEN (Senegal); TGO (Togo) and GHA (Ghana)

Calculated from IMF -WEO'S Country data, 2017

Table 3: GDP Per Capita of ECOWAS Countries

\begin{tabular}{|l|r|r|r|r|r|r|r|r|r|r|r|}
\hline \multicolumn{1}{c|}{} & $\mathbf{2 0 0 6}$ & $\mathbf{2 0 0 7}$ & $\mathbf{2 0 0 8}$ & $\mathbf{2 0 0 9}$ & $\mathbf{2 0 1 0}$ & $\mathbf{2 0 1 1}$ & $\mathbf{2 0 1 2}$ & $\mathbf{2 0 1 3}$ & $\mathbf{2 0 1 4}$ & $\mathbf{2 0 1 5}$ & $\mathbf{2 0 1 6}$ \\
\hline Benin & 1753 & 1805.6 & 1841.2 & 1831.8 & 1818.8 & 1820.9 & 1855.8 & 1934.6 & 2001.1 & 1987.2 & 2010 \\
\hline Burkina Faso & 1305.9 & 1338.8 & 1393.7 & 1392.2 & 1423.4 & 1472.7 & 1521.5 & 1562.3 & 1582.3 & 1596.3 & 1642.2 \\
\hline Cabo Verde & 4949.2 & 5633.9 & 5944 & 5806.6 & 5828.2 & 5991.8 & 5986.9 & 5963.9 & 5928.2 & 5918.6 & 6074.8 \\
\hline Côte d'Ivoire & & & 2576.5 & 2596.2 & 2589.3 & 2413.6 & 2625.2 & 2750.7 & 2971.3 & 3132.5 & 3310.4 \\
\hline Gam bia, The & 1501.8 & 1507.7 & 1544.5 & 1593 & 1644.2 & 1524.8 & 1560.3 & 1584.7 & 1550.2 & 1568 & 1554.9 \\
\hline Ghana & 2632 & 2675.4 & 2845.2 & 2907.6 & 3059.4 & 3404.5 & 3632.4 & 3807.3 & 3868.6 & 3929.7 & 3980.2 \\
\hline Guinea & 1510.1 & 1574.1 & 1603.4 & 1543.8 & 1575.4 & 1625.6 & 1684.1 & 1711.7 & 1734.7 & 1753.1 & 1823.3 \\
\hline Guinea -Bissau & 1338.3 & 1349.4 & 1359.9 & 1371.1 & 1400.4 & 1475.4 & 1413 & 1421.3 & 1398.3 & 1446.5 & 1491.7 \\
\hline Liberia & 624.05 & 656.87 & 674.98 & 683.06 & 699.65 & 734.33 & 771.91 & 818.59 & 804.72 & 785.25 & 753.56 \\
\hline Niger & 777.88 & 773.02 & 815.97 & 780.17 & 813.98 & 801.6 & 862.59 & 873.8 & 904.16 & 904.58 & 914.47 \\
\hline Niqeria & 4374.3 & 4551.6 & 4710.6 & 4904.9 & 5150.2 & 5259.3 & 5339.5 & 5479.1 & 5671.9 & 5670.6 & 5434.7 \\
\hline Seneqal & 2102.5 & 2147.4 & 2166.2 & 2157.4 & 2184 & 2158.2 & 2187.2 & 2196 & 2218.6 & 2293.9 & 2379.5 \\
\hline Sierra Leone & 1070.3 & 1124.5 & 1156.4 & 1182.4 & 1217.2 & 1246.3 & 1402.7 & 1655.1 & 1692.1 & 1316 & 1368.8 \\
\hline Togo & 1195.7 & 1190.6 & 1184.6 & 1193.5 & 1208.3 & 1233.8 & 1259.3 & 1275.2 & 1315.3 & 1349.4 & 1382.1 \\
\hline Mali & 1783.1 & 1784.9 & 1808.9 & 1832.8 & 1872 & 1874.7 & 1804.9 & 1793.7 & 1865.2 & 1919.2 & 1971.1 \\
\hline
\end{tabular}

Source: Calculated from IMF-WEO'S Country data, 2017

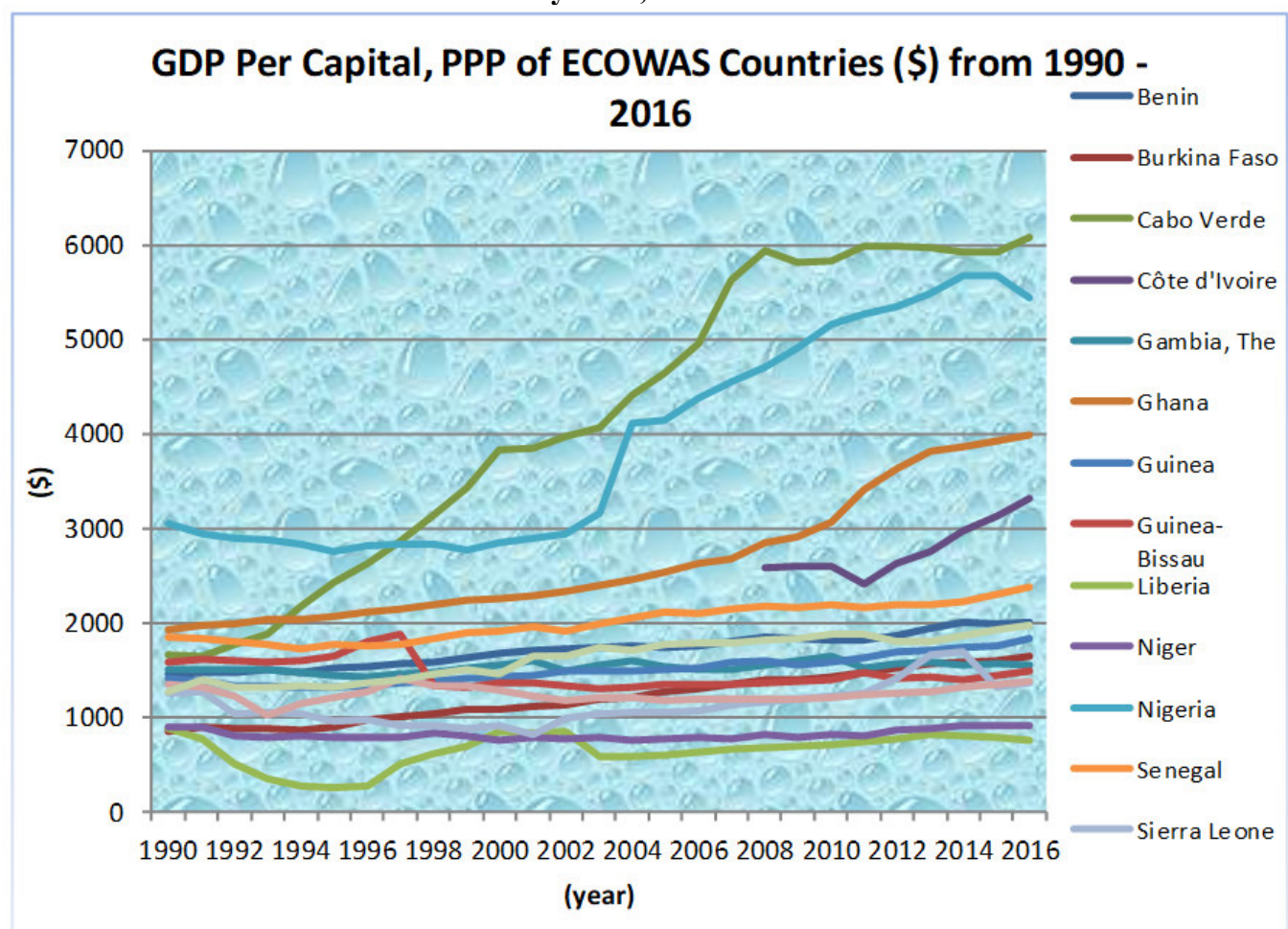

Fig. 1. GDP Per Capita, PPP of ECOWAS Countries 


\subsubsection{Financial Intermediation in Nigeria}

In Nigeria, economic development involves activities of both the private and public sectors which require capital. Financial intermediation, therefore, provides the platform for credit and financial products accessibility in the economy. Financial intermediation is an integral part of the Nigerian economy, enabling specialized institutions to provide intermediation avenues for channeling and rechanneling funds and assets from surplus terminals to deficit terminals. It creates opportunities for effective indirect interactions between fund suppliers (lenders) and fund raisers (borrowers) which ultimately create wealth.

Financial intermediation enables participants in the Nigerian financial market to attain objectives that would have ordinarily been unattainable in the absence of financial intermediaries. It provides beneficial information to both savers and creditors thus facilitating and deepening financial markets. Commercial banks in Nigeria are the major financial intermediaries through which credit creation occurs to provide a pool of investment funds for borrowers with fees charged for financial intermediary services. Commercial banks are deposit taking financial institutions, and they make profit by lending at higher interest rates than the rate they pay on deposits. They also offer a wide range of financial services to their customers such as loans, foreign exchange facilities etc. According to Joseph Schumpeter (1911) bank financial intermediation does not only entail creation of a pool of investible funds, it also involves allocating funds. The Central Bank of Nigeria also provides financial intermediation in Nigeria by acting as the lender of last resort both to the commercial banks and the government.

Ikhide (1997) asserts that the financial system in Nigeria is dominated essentially by the banking sector, while Itewe (1983), Babalola (1989), Akingbade (1983) and Ojo (1994), highlighted the financial intermediary functions of banks in the Nigerian economy and conclude that banks have the potential to increase deposit mobilization for productive investment in Nigeria.

Table 6 below shows a number of some financial intermediation variables, namely: net bank credit to the government, net bank credit to the private sector, prime and maximum lending rates, plus broad money supply M2, from year 2000 to 2017, which can influence the effectiveness of financial intermediation in the Nigerian economy. Table 6: Selected Financial Intermediation Macroeconomic Variables in Nigeria, 2000 - 2017

\begin{tabular}{|l|l|l|l|l|l|}
\hline Year & M2 (Money Supply) & $\begin{array}{l}\text { Prime } \\
\text { lending } \\
\text { Rates }\end{array}$ & $\begin{array}{l}\text { maximum } \\
\text { lending Rates }\end{array}$ & $\begin{array}{l}\text { Net Credit to } \\
\text { Government }\end{array}$ & $\begin{array}{l}\text { Credit to the } \\
\text { Private Sector }\end{array}$ \\
\hline & M2 (Money Supply) & PRATE & MAXRATE & NCG & CPS \\
\hline 2000 & 48.07 & 17.98 & 21.55 & -170.13 & 30.93 \\
\hline 2001 & 27 & 18.29 & 21.34 & 95.16 & 43.46 \\
\hline 2002 & 21.55 & 24.85 & 30.19 & 63.55 & 11.79 \\
\hline 2003 & 24.11 & 20.71 & 22.88 & 58.43 & 26.81 \\
\hline 2004 & 14.02 & 19.18 & 20.82 & -17.94 & 26.61 \\
\hline 2005 & 24.35 & 17.95 & 19.49 & -36.99 & 30.82 \\
\hline 2006 & 43.09 & 17.26 & 18.7 & -732.81 & 32.06 \\
\hline 2007 & 44.8 & 16.94 & 18.36 & -22.3 & 91.62 \\
\hline 2008 & 57.88 & 15.14 & 18.7 & -31.21 & 59.49 \\
\hline 2009 & 17.07 & 18.99 & 22.62 & 25.92 & 26.15 \\
\hline 2010 & 6.91 & 17.59 & 22.51 & 51.27 & -3.81 \\
\hline 2011 & 15.43 & 16.02 & 22.42 & 22.6 & 44.28 \\
\hline 2012 & 16.39 & 16.79 & 23.79 & -138.04 & 6.83 \\
\hline 2013 & 1.2 & 16.72 & 24.69 & 40.14 & 8.96 \\
\hline 2014 & -0.56 & 16.47 & 25.74 & -0.74 & -0.83 \\
\hline 2015 & 18.87 & 16.91 & 26.71 & 21.67 & 22.41 \\
\hline 2016 & 25.92 & 16.87 & 27.29 & 43.67 & 25.29 \\
\hline 2017 & 22.19 & 16.87 & 29.07 & 51.13 & 22.09 \\
\hline
\end{tabular}

Source: $C B N, 2017$ 


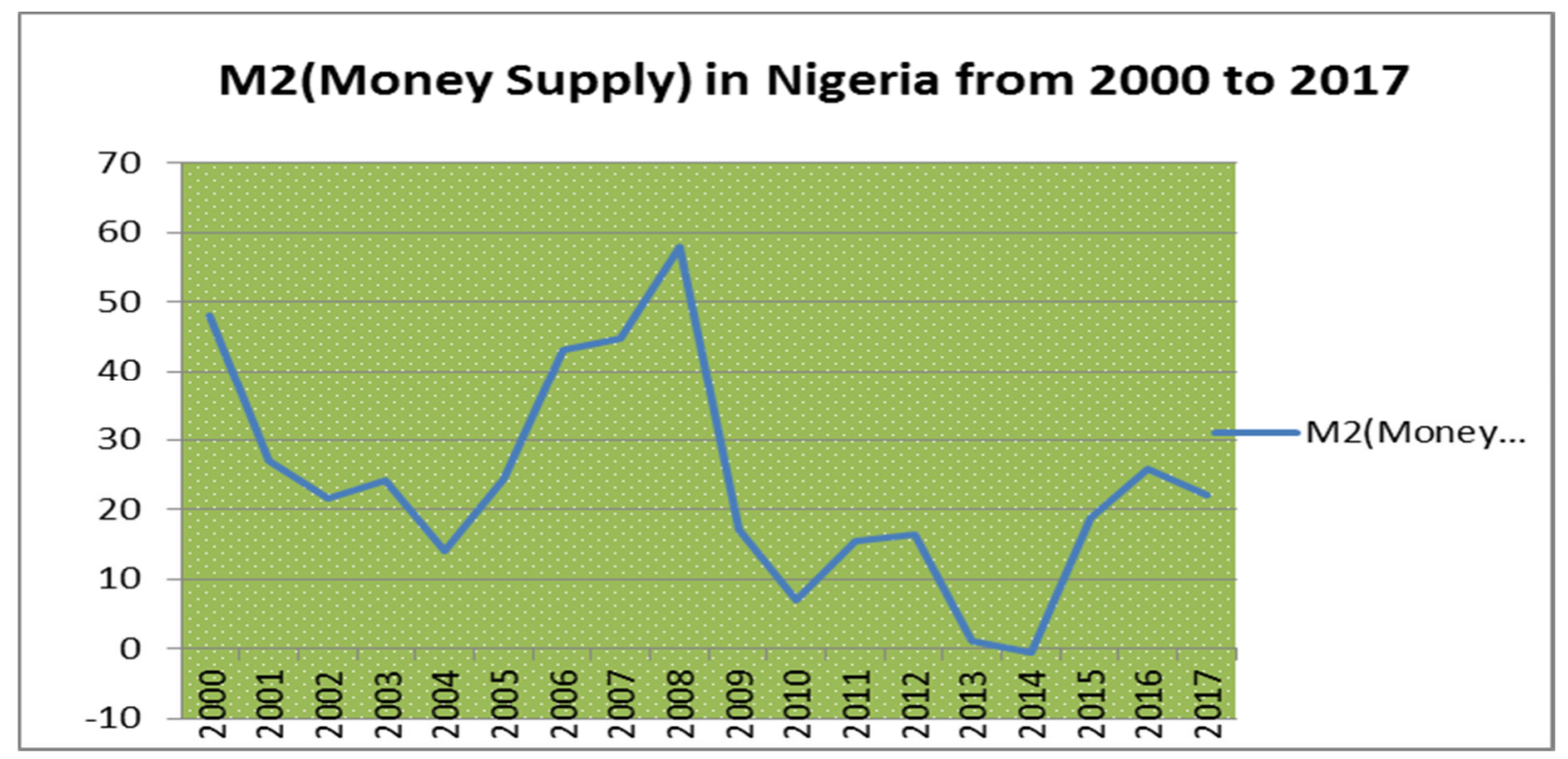

Source: $C B N, 2017$

Fig. 2. Broad Money (M2) in Nigeria from 2000 to 2017

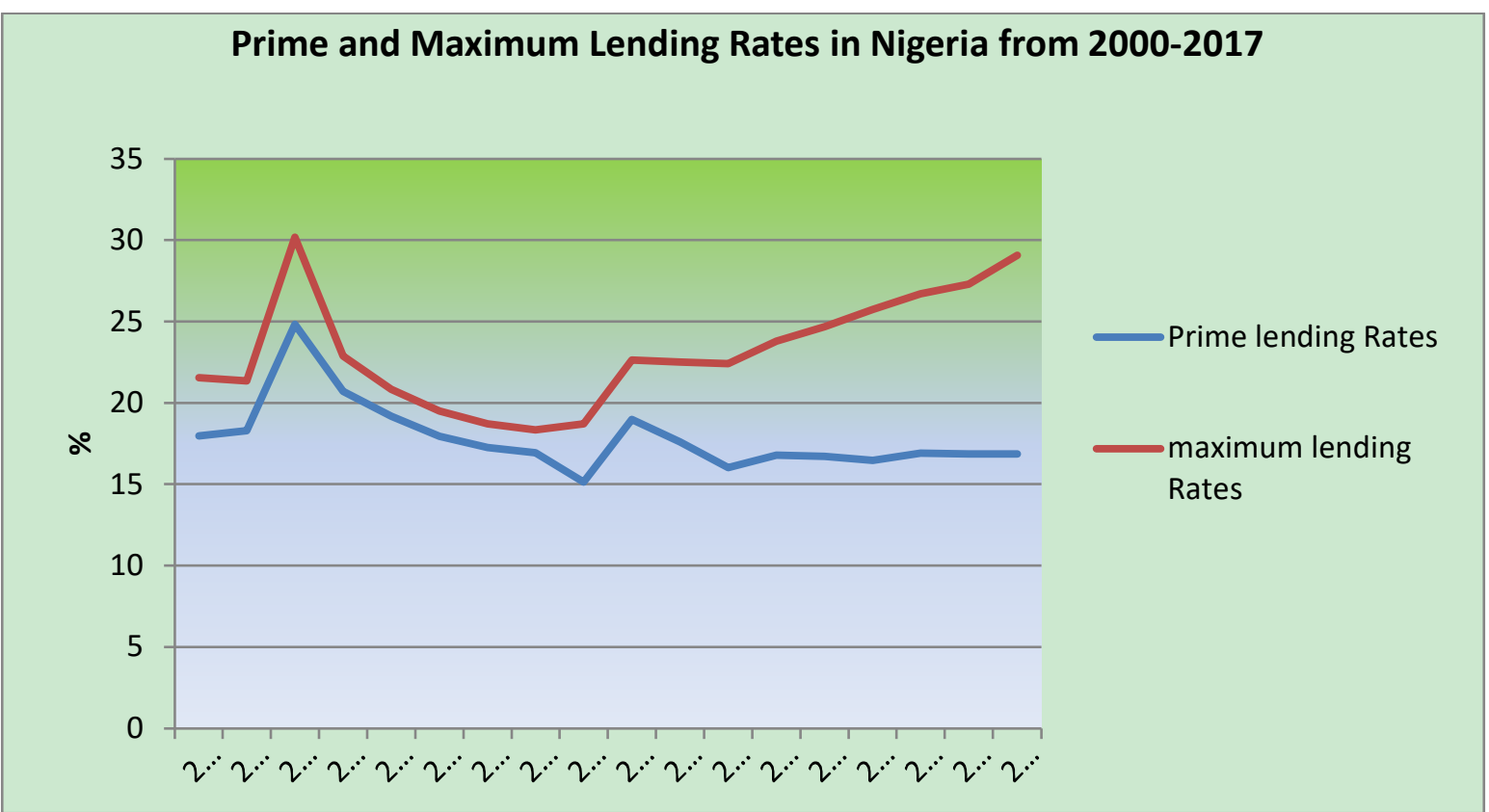

Source: $C B N, 2017$

Fig 3. Prime and Maximum Lending Rates in Nigeria from 2000 to 2017

The Table and Charts above show the trends of some selected financial variables in Nigeria (net bank credit to the government, net bank credit to the private sector, prime and maximum lending rates, plus broad money supply M2) from year 2000 to 2017. For example, the fluctuation in broad money (M2) in Figure 2 above indicates some degree of volatility which can be attributed to different episodes of liquidity shocks and their management by the monetary authority plus macro-economic conditions in the country during the period. However, the level of M2 in Nigeria at any given time is expected to impact on the liquidity conditions, thereby influencing financial intermediation as banks can only provide credit from available liquidity. This is expected to ultimately impact on economic activity. Okorie's, (2013) findings confirmed the above by reporting the existence of a significant positive relationship between credit to the private sector and domestic investment, where a $10 \%$ increase in the credit to the private sector resulted in $6 \%$ increase in domestic investment in the Nigerian economy. In the same vein, Emecheta and Ibe, (2014) revealed that a significant relationship exists between bank credit to the private sector, broad money, and economic growth. In furtherance to the above observations, Demettriades and Hussein (1994), demonstrated that the provision of adequate credit to the private sector, can generate increased investment and productivity in developing countries. 
In the same vein, the downward and upward movements of the prime and maximum lending rates in the chart above (see fig.3) show the behavior of the above lending rates in the Nigerian financial market from year 2000 to year 2017. The above trend can have implications on financial intermediation, which also affect the costs and access to credit, and ultimately economic activity and performance.

Table 6 also shows net credit to the government and private sector from 2000 to 2017. From the table, it is apparent that there exists some degree of inequity in financial intermediation in credit provision for the government and the private sector, in favor of the government against the private sector. The implication of the above is that the contribution of the private sector to economic in Nigeria will be hindered as a result of insufficient credit facilities, thus affecting employment rate and economic growth in the country. Another implication of the lopsided distribution of credit between the two segments of the economy is ineffectiveness in financial intermediation which can negatively affect the country's economic growth.

\subsection{Methodology}

4.1 The Model

The study employs the autoregressive distributed lag (ARDL) approach to co-integration. ARDL (p, q) is a workhorse in single dynamic equation models for macroeconomic analysis and forecasting, especially in the long horizon (Hanif and Malik, 2015), and (Hassler and Wolters, 2006). The ARDL is unique in capturing the dynamics and peculiarities of an economy, and provides significant model space for data admissibility, given that the much touted unit root and co-integration regression are sensitive to a number of observations and specifications (Pesaran and Shin, 1997) and (Bardsen, Eitheim, Jasen, \& Nymoen, 2005).

$\Delta y_{t}=\alpha+\sum_{i=1}^{p} \phi_{i} y_{t-i}+\beta^{\prime} x_{t}+\sum_{i=0}^{q-1} \beta^{*}{ }^{\prime} \Delta x_{t-i}+\mu_{t}$.

We estimated four ARDL models to capture the impact of ECOWAS integration on financial intermediation in Nigeria. The four models are differentiated by the type of financial development indicator (FD) used as the dependent variable. Thus, in Model 1, the natural logarithm of the composite financial development indicator (Fin Index) computed from the three FD indicators, was the dependent variable. In Model 2, the dependent variable is the natural logarithm of ratio of credit to the private sector provided by commercial banks to national GDP (CPS GDP) while Model 3's dependent variable is natural logarithm of the ratio of broad money supply (M2) to GDP (M2_GDP). Model 4, therefore, is the natural logarithm of ratio of commercial bank's assets to the combination of commercial banks' and central bank's assets (COMB ASSETS). The explanatory variables included in the four models are the same. Thus, after taking the natural logarithm of the variables, the four estimated models can be generically represented as follows:

$$
\ln F D I_{t}=\beta_{0(t-i)}+\ln F D I_{(t-i)}+\beta 1 \ln E C O G D P_{(t-i)}+\beta_{2} \ln E C O T R A D E_{(t-i)}+\beta_{3} \ln M P R_{(t-i)}
$$$$
+\beta_{4} \operatorname{INFLA}_{(t-i)}+\beta 5 \ln G O V \operatorname{TEXP}_{(t-i)}+\beta_{6} \ln O P E N N E S S_{(t-i)}+u_{(t-i)}
$$

where FDI represents the financial development variable, which is either Fin_Index, or CPS_GDP, or M2_GDP or COMB_ASSETS; $t$ is time trend; and $u$ is a white noise error term. The control variables included ECOWAS macroeconomic aggregates, mainly total regional trade (ECOTRADE) and regional real per capita income (ECOGDP). We also included other control variables, consisting of domestic inflation rate (INLFA), monetary policy rate (MPR), trade openness (OPENNESS) and government expenditures (GOVT_EXP). The error correction form of ARDL model specified in Eq. 2 is as follows:

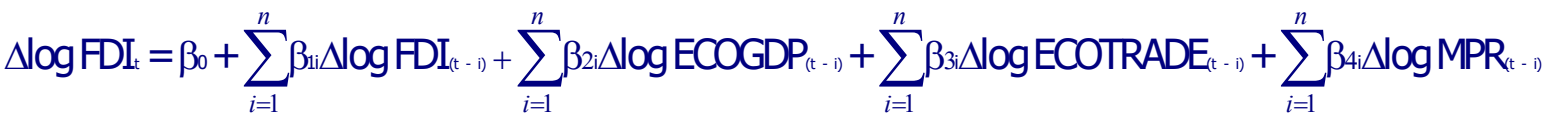

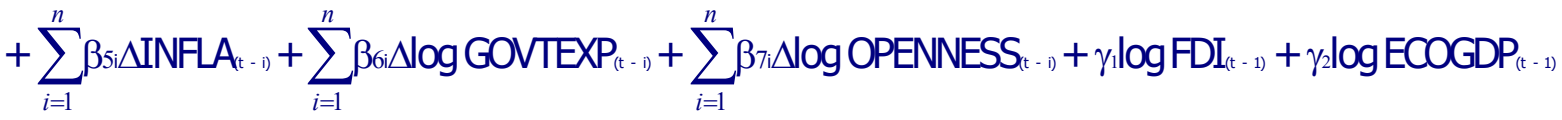

$$
\begin{aligned}
& +\gamma_{3} \log \text { ECOTRADE }_{(t-1)}+\gamma_{4} \log \operatorname{MPR}_{t-1)}+\gamma_{5} \operatorname{INFA}_{(t-1)}+\gamma_{6} \log \operatorname{GOVITXP}_{(t-1)}+\gamma_{1} \log \operatorname{OPENNESS}_{(t-1)}+u_{(t-1)}
\end{aligned}
$$

To determine the long run relationships among the model variables, we tested the following hypotheses. The null hypothesis was defined as $\mathbf{H}_{0} \gamma_{1}=\gamma_{2}=\gamma_{3}=\gamma_{4}=\gamma_{5}=\gamma_{6}=\gamma_{7}=0$ using F-statistic.

The asymptotic distribution of the F-statistic is expected to be non-standard whether the series are I(0) or I(1). Pesaran et al (2001) estimated two sets of critical values, namely one set for I(0) variables and the other set for I $(1)$ variables. These critical values provide a range for all possible classifications of the model variables into I( 0$)$, I(1) and fractionally integrated variables. When combined with F-statisitic, we can test the existence of a long-run 
relationship among model variables. If the calculated F-statistic lies above the upper limit of the critical values, the null was rejected, indicating presence of cointegration. On the contrary, if the calculated F-statistic is below the lower limit of the range, the null hypothesis was accepted, indicating absence of cointegration. If it lies within the range, the result is indeterminate.

Where there is evidence for the existence of cointegration (or long-run relationship) among variables, we would select the appropriate lag orders of the dependent variable along with regressors in the model to arrive at conditional or restricted ARDL model. On the contrary, where there is no evidence of long-run relationship, we would adopt unrestricted or non-conditional ARDL as specified in equation 2.

To achieve unbiased and consistent/efficient estimates, the unrestricted ARDL equation (2) was tested for a number of statistical diagnostic properties. These included the tests for serial correlation (Breusch-Godfrey test), normality (Jarque-Bera normality test) and heteroscedasticity. In addition, the stability of the estimated coefficients over the sample period was also tested by the recursive residual test for structural stability.

The overall objective is to identify a variety of indicators of financial development in Nigeria, which are then regressed on a number of independent variables. Therefore, the first task was to identify and define the four popular measures of financial development. The first measure is the ratio of credit to private sector provided by commercial banks to national GDP (CPS_GDP), indicating the critical role played by the financial sector, especially commercial banks in the financing of the Nigerian real economy. It does not include credit issued to governments and public enterprises, but only considers credit to the private sector by commercial banks and other financial institutions (OFIs). This type of credit increases investment and productivity to a much wider and larger degree than credit to the public sector.

The second is the ratio of broad money supply (M2) to GDP (M2 GDP), which measures financial depth, and indicates the overall size of financial intermediation. Finally, the third measure of financial intermediation is the ratio of commercial bank's assets to the combination of commercial banks' and central bank's assets (COMB_ASSETS). The third indicator proxies the influence of the commercial banking sector in the economy and as commercial banks' assets increase, the indicator becomes a good proxy for the financial sector development.

In addition, we introduced a fourth indicator of financial intermediation or financial development (FD), namely fin_Index. This index is computed as a composite of all three indicators described above using equation 4.

$$
\frac{1}{n} \sum_{j=1}^{n}\left[100 *\left(\frac{F_{j, t}}{\bar{F}}\right)\right]
$$

$F$ represents the financial development (intermediation) indicators described above and $F$ (bar) is their means.

The decision to use a composite FD index is predicated on the work of Levine (1997), which stated that FD should involve improvement in a number of key business functions. Accordingly, Aziakpono (2004) surmised that if the functional definition is accepted, then a single indicator may not adequately measure financial development. Consequently, a measure of financial services development should reflect the different functions of the financial system. In addition, we included other control variables, consisting of ECOWAS and Nigerian macroeconomic variables in the analysis.

The rate of inflation and government expenditure can popularly serve as indicators of macroeconomic stability. High inflation hampers investment, thereby reducing economic activity and adversely impacting on financial intermediation. The measure of inflation in the study refers to the percentage changes in the CPI over a specific base year.

Government expenditure, on the other hand, may have counteracting implications for financial intermediation. It enhances financial intermediation as it provides alternative source of liquidity to the real economy, especially in the peculiar circumstances of the developing countries. However, it can reduce economic activity, thereby stoking financial intermediation because of its crowding out effect on the private sector with implications for inflation. Government expenditure variable is computed as the percentage share of government expenditure in the GDP. The degree of openness in the analysis captures the effects of international trade on growth, and is computed as the sum of imports and exports as a percentage of nominal GDP. Similar to government expenditure, trade openness can have either a positive or negative impact; thus requiring an empirical determination of the net effects.

Trade openness affects financial intermediation indirectly. The openness of the trade regime positively impacts economic activity (Odhiambo, 2011; Pagano,1993; and Rajan and Zingales, 2003), thereby accelerating the degree of financial development. On the flipside, openness can also adversely impact growth, in instances where the import of consumer goods dominates the country's trade. In that case, openness becomes detrimental to financial intermediation. 


\subsection{Data}

Two sets of data were collected and used in the study. First, is the ECOWAS regional data, including Per Capita GDP and total regional trade. Second, is the Nigeria macroeconomic data, including inflation, real GDP, credit to private sector, money supply (M2), government expenditure, monetary policy rate (MPR), monetary authority's assets as well as assets of the entire banking system. Data sources include Central Bank of Nigeria (CBN) Statistical Database, ECOWAS region's central banks' databases, to name a few.

\subsection{Model Results and Discussion}

To properly implement the ARDL framework we tested for the order of integration, primarily to ensure that the variables are only $\mathrm{I}(1)$ or $\mathrm{I}(0)$, and avoid spurious results. In addition, the cointegration test is based on the assumption that the model variables are either 1(0) or 1(1). Therefore, unit root tests were carried out to ensure that no variable is 1(2) or more. The ADF tests are reported in Table 7, and indicate that all except for Inflation and ratio of M2 to GDP, model variables are integrated of order one i.e. they are stationary after first difference. This result supports the application of ARDL methods in using bounds cointegration method in determining the long-run relationships among model variables. The null hypothesis, therefore, is that the variables have a unit root (i.e. it is non-stationary). The alternative hypothesis is that the variables have no unit root (i.e. it is stationary). In almost all cases, we did not reject the null hypothesis. Prelimary tests indicate that there is no serial correlation, and that the model was stable in the long run. The cointegration tests indicate the absence of long run relationships among the model variables, once again validating the use of unrestricted ARDL technique.

\section{Table 7: Unit Root Test Results}

$\begin{array}{lll}\text { Variables } & \text { Variable } & \begin{array}{c}\text { Unit Root } \\ \text { Test }\end{array} \\ \text { Policy rate } & \text { Code Name } & \text { I(1) } \\ \text { Composite Financial Development Indicator } & \text { MPR } & \text { I(1) } \\ \text { Ratio of M2 to GDP } & \text { FIN_INDEX } & \text { I(0) } \\ \text { Ratio of Credit to Private Sector to GDP } & \text { M2_GDP } & \text { I(1) } \\ \text { Ratio of Comm. Banks' Asset to Total Assets } & \text { CPS_GDP } & \text { I(1) } \\ \text { Openness of the Economy } & \text { COMB_TOASSETS } & \text { I(1) } \\ \text { Inflation } & \text { OPENNESS } & \text { I(0) } \\ \text { Government Expenditure } & \text { INFLA } & \text { I(1) } \\ \text { Per Capita Income in ECOWAS Region } & \text { GOVT_EXP } & \text { I(1) } \\ \text { Total Volume of Trade in ECOWAS Region } & \text { ECOGDP } & \text { I( }(1)\end{array}$

Source: Author's computation from Eview, 2019

The critical bounds of the F-statistic from the estimated equation for $\mathrm{I}(0)$ and $\mathrm{I}(1)$ at $1 \%$ and $5 \%$ are depicted in Table 8 and the estimated the coefficients of the ARDL models are shown in Table 9.

Table 8: Cointegration Test: Dependent Variable

\section{Financial Development Indicator}

LOG(FIN_INDEX)
LOG(M2_GDP)
LOG(CPS_GDP)
LOG(COMB_TOASSETS)

F-Statistic

3.68
4.32
4.78
1.37

Critical Bounds of the F-Statistic $1 \%$ Level $\mathrm{I}(0)$
$\mathrm{I}(1)$

$$
6.84
$$

\section{Source: Author's computation. Critical values from Pesaran et al. (2001)}

The cointegration tests indicate the absence of long run relationships among the model variables, once again validating the use of unrestricted ARDL technique.

In the final runs of the ARDL models, a number of variables were significant as depicted in Table 9. In the four models, the result indicates that history of financial intermediation (lagged FD variable) has a positive sign and was significant, indicating it significantly promotes current financial intermediation in line with a priori expectation. In Model 1, a $0.25 \%$ increase in the composite financial indicator is attributable to a $1 \%$ increase in its previous history. In Model 2, a 1\% increase in the previous history of financial depth (as measured by the ratio of broad money supply (M2) to GDP) could cause a $0.52 \%$ increase in the current financial intermediation. Similarly, it would cause $0.50 \%$ and $0.61 \%$ increases in the current level of financial intermediation when credit to private sector and ratio of commercial banks' assets to total industry assets are the indicators of financial intermediation, respectively.

In Model 1, which uses a composite indicator of FD as the dependent variable, all the remaining independent variables have the right signs although they were not significant except real per capita income in the ECOWAS region, which proxies the level of economic activity and development. This suggests that as incomes of the region increase, more financial services are required, thereby expanding the financial sector of member states, especially 
Nigeria. This finding may be indicating that economic activity in the region may be having positive impact on financial intermediation in Nigeria. Thus, a $1 \%$ increase in the real per capita income in the ECOWAS region would lead to $1.20 \%$ improvement in financial intermediation of the Nigerian financial services. However, we could not replicate this finding when other three indicators were used separately as independent variables. The degree of trade in the region captured by the variable, ECO_TRADE, has a positive relationship with financial intermediation in Nigeria in all except model 4, suggesting that regional trading activities improve the country's financial intermediation. However, the improvement is not significant.

In general, therefore, ECOWAS regional economic variables were not significant in determining the level of financial intermediation in Nigeria. This finding may be suggesting that, although economic activity has increased in the region over time due to ECOWAS integration, it has, however, not led to significant improvement in financial intermediation in Nigeria. It also suggests that the two regional variables do have positive relationship with financial intermediation indicators, indicating they ordinarily contribute to financial intermediation in Nigeria. However, their contributions are not significant. This finding is contrary to popular expectation given the increase in integration and improvement in economic cooperation among member states.

Common across all models is that history (past values) of all dependent variables is positive and significant in determining their future trajectories. This indicates firmly that domestic macroeconomic developments in Nigeria, especially those relating to broad money supply (M2), credit to private sector and overall commercial banks' assets are major determinants of the country's financial development. Thus, domestic developments rather than ECOWAS-related developments are significantly responsible for the levels of financial intermediation and financial development in the country. In the model 2, a 10 per cent change in previous history of financial intermediation cause over 5 per cent change in current financial development (intermediation). This finding is replicated for Model 3, indicating that history of credit to private sector can improve the current level of credit to the private sector, a key indicator of not only financial development but also of economic growth. In Model 4, the history of commercial banks' assets is also positive and significant, with a 10 per cent change in it causing over 6 per cent improvement in the current levels of financial intermediation. Therefore, any effort aimed to improve FD or financial intermediation in Nigeria should involve measures that support improvement in money supply, credit to the private sector and commercial banks' assets.

In addition, other domestic economic variables, namely the Nigerian monetary policy rate (MPR), inflation, government expenditure and trade openness, have the appropriate signs in line with a priori expectation. The policy rate is negatively signed in all models, indicating an increase in the rate adversely affects financial intermediation in Nigeria. This variable was barely significant at 10 per cent in one of the models. This development occurs because higher MPR reduces system liquidity, hampering economic activities, thereby reducing banking intermediation activities.

Similarly, inflation has negative relationship with financial intermediation in all models, but it is not significant. The negative relationship may imply that an increase in the rate of inflation adversely impact credit market causing friction and worsening FD. Higher inflation rate depresses the rate of real returns on assets, thereby worsening credit market friction, resulting in fewer loans, inefficient allocation of resources and reduced intermediation.

Trade openness also has a negative relationship with financial intermediation, although it was not significant in all models. This may suggest that increase in trade openness may be inimical to financial intermediation in Nigeria as the country is a net importer. Again, this supports the finding discussed above that domestic, rather than external, developments support financial intermdediation in Nigeria. 
Table 9: Results of the ARDL Alternative Models

\begin{tabular}{|c|c|c|c|c|}
\hline & $\begin{array}{l}\text { (1) Composite } \\
\text { FD Indicator }\end{array}$ & $\begin{array}{l}\text { ARDL Models } \\
\text { (2) Broad } \\
\text { Money } \\
\text { Supply to } \\
\text { GDP }\end{array}$ & $\begin{array}{l}\text { (3) Credit to } \\
\text { Private Sector }\end{array}$ & $\begin{array}{l}\text { (4) Commercial Banks } \\
\text { Assets to Total Assets }\end{array}$ \\
\hline & $\begin{array}{l}\text { LOG(FIN_IND } \\
\text { EX(-1)) }\end{array}$ & $\begin{array}{c}\text { LOG(M2_G } \\
\text { DP(-1)) }\end{array}$ & $\begin{array}{l}\text { LOG(CPS_G } \\
\text { DP(-1)) }\end{array}$ & $\begin{array}{c}\text { LOG(COMB_TOASS } \\
\text { ETS(-1)) }\end{array}$ \\
\hline $\begin{array}{l}\text { Lag Dependent Variable } \\
\text { Coeff.: } \\
\text { Independent Variables } \\
\text { Coeff.: }\end{array}$ & $0.249542 * * *$ & $0.516295^{*}$ & $0.502934 *$ & $0.616036^{*}$ \\
\hline MPR & -0.018376 & -0.01317 & $-0.15005 * * *$ & -0.105803 \\
\hline LOG(ECO_TRADE(-1)) & 0.04034 & 0.086388 & 0.094078 & -0.065653 \\
\hline LOG(ECO_PCAPITA(- & $1.197494 * *$ & 0.242257 & 0.608541 & 0.929587 \\
\hline INFLA(-1) & -0.000809 & -0.00166 & $-5.78 \mathrm{E}-05$ & -0.000291 \\
\hline LOG(GOVT_EXP(-1)) & 0.007216 & 0.006213 & 0.007135 & $0.024658 * * *$ \\
\hline LOG(OPENN̄ESS(-1)) & -0.043364 & -0.00928 & 0.003121 & -0.042752 \\
\hline C & -6.401955 & -2.6468 & -5.42024 & -5.44128 \\
\hline
\end{tabular}

$*, * *, * * *$ indicates 1,5 and 10 per cent significance respectively Source: Compiled from Eview, 2019

\subsection{Conclusion and Policy Implications}

The study employed the autoregressive distributed lag (ARDL) approach to co-integration which is known for its uniqueness in capturing the dynamics and peculiarities of an economy, and estimated four different models with a view to capturing the impact of ECOWAS integration on financial intermediation in Nigeria. The four models were differentiated by types of financial development indicators (FD) used as dependent variables in the different models. The dependent variables which also served as proxies for financial intermediation in Nigeria are; ratio of credit to private sector provided by commercial banks to national GDP (CPS_GDP); ratio of broad money supply (M2) to GDP (M2_GDP); and ratio of commercial bank's assets to the combination of commercial banks' and central bank's assets (COMB_ASSETS) as well as their composite indicator (Fin Index). The explanatory variables included in the four models are the same. The control variables include ECOWAS macroeconomic aggregates namely; total regional trade (ECO_TRADE), regional real per capita income (ECOGDP) and regional inflation (ECO_INFLA). Other control variables used were; domestic inflation rates (INLFA), trade openness (OPENNESS) and government expenditures (GOVT_EXP). ADF test was conducted to test for unit root, and the result showed that all the model variables tested except for inflation and ratio of M2 to GDP are integrated of order one i.e. they are stationary after first difference, thus supporting the application of ARDL model to determine the long-run relationships among the model variables. The null hypothesis was not rejected as which states that the variables have a unit root.

The results of the models, however, indicate that the history of financial intermediation (lagged FD variables) was significant, thus indicating that it significantly promotes current financial intermediation in line with a priori expectation. ECOWAS regional economic variables on the other hand were generally not significant in determining the level of financial intermediation in Nigeria, thereby suggesting that, although economic activities may have increased in the ECOWAS region over time as a result of ECOWAS integration, such activities, however, have not led to significant improvement in financial intermediation in Nigeria. This finding is significant as it contradicts popular expectation in the face of the increase in the degree of integration and improvement in economic cooperation between member states over time. However, domestic developments, especially those relating to money supply, credit to the private sector and commercial banks activities, are major determinants of FD and financial intermediation in Nigeria. The fact that trade openness is similarly not helpful to the Nigerian financial sector further supports the finding that external factors (especially those relating to the ECOWAS region) do not significantly support financial sector development in Nigeria.

The policy implication, therefore, is that the economic integration of the ECOWAS region is apparently not directly beneficial to the Nigerian financial system, and may not enhance credit supply, capital accumulation, investment expansion and eventually economic growth in Nigeria. This finding reveals the gross imbalance between Nigerian and other ECOWAS financial sectors, as the Nigerian financial sector dominates the region. 
Thus, the flow of benefits is from Nigerian financial sector to other ECOWAS countries' financial sectors, which mostly benefit from the Nigerian financial system. In view of the above finding, it is imperative to carry out a further analysis of the costs and benefits of ECOWAS economic integration to the Nigerian financial system to guide policy. This should further help to reposition the country's financial sector to benefit from the great promises that ECOWAS monetary integration holds to member states.

As domestic developments are found to be significantly responsible for the country's financial sector development, it becomes imperatibve for fiscal and monetary authorities to intervene appropriately to ensure that developments in the domestic monetary conditions and credit availability and access are improved. This suggests the need for the Central Bank of Nigeria to intensify its effort in improving banking system liquidity and ensuring that all deposit money banks (DMBs) and other key stakeholders are involved in full-scale banking intermediation. This may also involve reducing lending rates and enhancing credit access to the private sector to stimulate the productive sectors of the economy and ensure robust growth.

\section{References}

1. R.T.Daimov, Modelling international economic integration: an oscillation theory approach, Victoria, Trafford, 2008, $234 \mathrm{p}$

2. Ravshanbek Dalimov, The heat equation and the dynamics of labor and capital migration prior and after economic integration, African Journal of Marketing Management vol. 1 (1), pp. 023-031, April 2009

3. Jovanovich, M. International Economic Integration. Limits and Prospects. Second edition, 1998, Routledge.

4. Michael P. Okom, (2016), Economic Integration In ECOWAS: 40 Years After, European Scientific Journal July 2016 edition vol.12, No.19 ISSN: 1857 - 7881 (Print) e - ISSN 1857- 743175

5. ECOWAS Executive Secretary`s Report, 2003.

6. 6. G. Obiozor et al, (ed.) Nigeria and the ECOWAS Since 1985: Towards a Dynamic Regional Integration, Nigeria Institute of International Affairs, Lagos: Fourth Dimension Publishers, Enugu.

7. G. Modelski, A Theory of Foreign Policy, London: Pall Mall, 1961. International Monetary Fund (IMF) Annual Report on Integration in Africa.

8. Okoi Arikpo "Nigeria and the O.A.U.'” Lecture Delivered at the Nigerian Institute of External Affairs, July 311974.

9. O.A.U. Report on Forum for Promotion of Financial Market of Integration and Development in Africa, 1997. (Article by A. Ekpe on 'Financial Market Integration and the Private Sector: The view from the Banking Sector'').

10. O.J Nnanna, (2005). Papers Presented at the 2005 Programme Implementation and Technical Review Meeting, by the Department of Planning, Research and Statistics of the Ministry of Cooperation and Integration (MCIA) July, 2005.

11. P. Masson and C. Pattilio, 'Monetary Union in West Africa, (ECOWAS): Is it Desirable can it be Achieved", www.inf.org. (2004, Last Visited 10-5-15).

12. J. Maudos and J. Fernández de Guevara (2015) The economic impact of European financial integration: The importance of the banking union. The Spanish Review of Financial Economics 2015; 13:11-9. Vol. 13, N0.1, January - June 2015.

13. European Central Bank (2012) Financial Integration in Europe, Frankfurt.

14. IMF Working Paper WP/12/161 (2012) Too Much Finance.

15. J. Fernández de Guevara, R. Inklaar,J. Maudos (2013) The impact of the financial crisis on financial integration and investment in the European Union. Investment and Investment Finance in Europe, European Investment Bank, (2013)pp. 207-240.

16. L. Guiso,T. Jappelli,M. Padula,M. Pagano (2004) Financial market integration and economic growth in the UE. Econ. Policy, October (2004), pp. 523-577.

17. London Economics (2002) Quantification of the Macro-Economic Impact of Integration of EU Financial Markets. Final Report to the European Commission.

18. J. Maudos,J. Fernández de Guevara (2011) Bank competition, financial dependence and economic growth Eur. J. Finance, 17 (2011), pp. 739-764.

19. R. Rajan,L. Zingales (1998) Financial dependence and growth. Am. Econ. Rev., 88 (1998), pp. 559-587 Journal of Economics Integration, 26(1), March 2011; 1-28

20. Allen, F. \& Gale, D. (2004). Financial Intermediaries and Markets. Econmetrika, 72(4), pp. 1023-1061.

21. Anad, A., \& Subrahmanyam, A. (2008). Information and Intermediary: Are Market Intermediaries Informed Traders in Electric Markets? Journal of Financial and Quantitative Analysis, 43 (1), pp. 1-28.

22. Araujo, L. \& Minetti, R. (2007). Financial Intermediaries as Markets for Firms' Assets. Economic Journal, 117, pp. 1380-1402.

23. Benston, G. \& Smith, Jr. (1975). A Transaction Cost Approach to the Theory of Financial Intermediation. Journal of Finance, 31(2), pp. 215-231. 
24. Gromb, D., \& Vayanos, D. (2010). A Model of Financial Capital Liquidity Based on Intermediary Capital. Journal of European Economic Association, 8(2 - 3), pp. 456-466.

25. Hao, C. (2006). Development of Financial Intermediation and Economic Growth: the Chinese Experience. China Economic Review, 17(4), pp. 347-362.

26. Holmstrom, B., \& Tirole, J. (1998). Private and Public Supply of Liquidity. Journal of Political Economy, 106(1), pp. 1-40.

27. King, R. \& Levine, R. (1993). Finance and Growth: Schumpeter Might be Right. The Quarterly Journal of Economics, 108, pp. 681-737.

28. Odedokun, M. (1998). Financial Intermediation and Economic Growth in Developing Countries. Journal of Economic Studies, 25(2-3), pp. 203-22.

29. Schumpeter, J. (1911). Theorie der wirtschaftlichen Entwicklung/Theory of Economic Development. München: Duncker \& Humblot.

30. Rajan, R., \& Zingales, L. (1998). Financial Dependence and Growth. American Economic Review, 88, pp. $559-5$

31. Odhiambo, N.M. 2011, "Financial deepening, capital influence and economic growth nexus in Tanzania: A multivariate model", Journal of Social Science, 28 (1): 65-71 (2011).

32. Pagano, M. 1993, "Financial markets and growth: an overview", European Economic Review, vol.37, no. 2 , pp. 613-622.

33. Rajan, R. G., \& Zingales, L. 2003, "The great reversals: the politics of financial development in the twentieth century", Journal of Financial Economics 69, 5-50.

34. Mahawiya, Sulemana 2015: Financial sector development, Inflation and Openness: A comparative panel study of ECOWAS and SADC, ERSA working paper 528.

35. Safiat Ali Saber Ali 2013: Financial Intermediation and Economic Growth in Sudan: An Empirical Investigation, 1970-2011. British Journal of Economics, Management \& Trade 3(4): 332-358, 2013.

36. Demirguc-Kunt, Asli and Harry Huizinga, 1999, Determinants of commercial bank interest margins and profitability: some international evidence, World Bank Economic Review 13, 379-408.

37. Odhiambo N. M. Financial Depth, Savings and Economic Growth in Kenya: A Dynamic Casual Relationship, Economic Model. 2008;25(4):704-713. 39

38. Ngugi, R.W., (2001). “An Empirical Analysis of Interest Rate Spread in Kenya”. African Economic Research Consortium, Research Paper 106

39. Brock, P.L, and Rojas-Suarez, L. (2000), "Understanding the behavior of bank spreads in Latin America", Journal of Development Economics Vol. 632000 113-134

40. Moore, W. and Craigwell, R. (2000) "Market Power and Interest Rate Spreads in the Caribbean", Paper Presented at the XXXII Annual Monetary Studies Conference, Kingston, Jamaica

41. Robinson, M., (2002), "Output -Purchase Funding and Budgeting Systems in The Public Sector". Public Budgeting and Finance, volume 22, issue 4, pages 17-33

42. Gelos, R.G., (2006), "Banking Spreads in Latin America", International Monetary Fund Working Paper $\mathrm{WP} / 06 / 44$

43. Sologoub, D. (2006). "The Determinants of Bank Interest Margins and Profitability: Case of Ukraine". Workshop on transition economics, Bank of Finland. Institute for Economies in Transition

44. Abiodun, O. F, and David, T.,(2009), "Determinants of Interest Rate Spreads in Sub-Saharan African Countries: A Dynamic Panel Analysis". A paper prepared for the 13th Annual African Econometrics Society Conference, Pretoria, Republic of South Africa

45. Crowley, J., (2007). "Interest Rate Spreads in English-Speaking Africa". IMF Working Paper. April 2007, $123-45$

\footnotetext{
AUTHORS

David E Omoregie, is Assistant Director (Economics), Monetary Policy Department, Central Bank of Nigeria $(\mathrm{CBN})$. He holds a PhD in Applied Economics, University of Aberdeen, United Kingdom, MSc and BSc degrees (Agricultural Economics), University of Ibadan, Nigeria. He also holds a Post-Graduate Diploma in Quantitative Techniques from the University of Aberdeen. Before joining the CBN, he worked for 20 years in various capacities as economist, manager and data scientist for UK financial institutions, including Lloyds TSB Bank, Egg Plc, and GE Life.

Ifeoma B. Ezike, is a Principal Economist, Monetary Policy Department, Central Bank of Nigeria (CBN). She holds a Master of Science (M.Sc.) Degree in Urban and Regional Planning from Obafemi Awolowo University, Ile-Ife, Osun State, Nigeria, Master of Business Administration (MBA) - Finance from Nasarawa State University, Nigeria, B.Sc. Urban and Regional Planning, from University of Nigeria Nsukka, Post graduate Diploma in Business Administration from Nasarawa State University, Nigeria, and Post Graduate Diploma in Economics from Nasarawa State University, Nigeria.
} 